\title{
ANALISA PERBAIKAN KUALITAS KONTRAS CITRA X-RAY MENGGUNAKAN METODE EXPOSURE BASED SUB-IMAGE HISTOGRAMEQUALIZATION (ESIHE)
}

\author{
Aditya Akbar Riadi \\ Fakultas Teknik, Program Studi Teknik Informatika \\ Universitas Muria Kudus \\ Email: aditya.akbar@umk.ac.id
}

\begin{abstract}
ABSTRAK
Perbaikan kualitas citra adalah proses dimana kualitas visual dari suatu citra ditingkatan sehingga didapatkan hasil yang lebih baik dari citra yang asli atau citra awal. Proses perbaikan kualitas citra dibagi menjadi dua domain yaitu domain frekuensi dan domain spasial. Dalam domain frekuensi, teknik beroperasi pada pemilihan frekuensi yang akan difilter. Sedangkan di domain spasial, teknik beroperasi secara langsung pada piksel citra. Pencahayaan berdasarkan gambar asli dan pemerataan histogram sub gambar terbukti sebagai teknik yang sangat efektif untuk meningkatkan pencahayaan yang kurang. Teknik perpotongan histogram juga dikombinasikan dengan pemerataan histogram. Hasil dari kombinasi kedua teknik ini mampumemberikan kontrol yang lebih dan menghasilkan peningkatan yang mengarah ke peningkatan alami.Langkah-langkah entropy dari metode ESIHE jelas menunjukkan bahwa hasil yang diperoleh mampu melebihi metode HE.Selain itu Kualitas visual gambar ESIHE menunjukkan hasil yang lebih baik dari pada metode HE untuk berbagai macam gambar $x$-ray.
\end{abstract}

Kata kunci: perbaikan kulitas citra, histogram equalization, esihe, entropy.

\section{ABSTRACT}

Image quality improvement is a process where the visual quality of an image to obtain better results than the image of the original or initial image. Image quality improvement process is divided into two domains, namely the frequency domain and spatial domain. In the frequency domain, operating on frequency selection techniques that will be filtered. While in the spatial domain, techniques operate directly on the image pixels. Lighting by the original image and sub-image histogram equalization proven very effective technique for improving poor lighting. Histogram intersection technique is also combined with histogram equalization to provide control over the increase leading to a natural increase. Steps entropy method ESIHE clearly shows that it exceeded HE method. The visual quality ESIHE image shows better results than the $H E$ method for a wide range of $x$-ray images.

Keywords: image quality improvement, histogram equalization, esihe, entropy.

\section{PENDAHULUAN}

Perbaikan kualitas citra adalah proses dimana kualitas visual dari suatu citra ditingkatan sehingga didapatkan hasil yang lebih baik dari citra yang asli atau citra awal. Proses perbaikan kualitas citra dibagi menjadi dua domain yaitu domain frekuensi dan domain spasial. Dalam domain frekuensi, teknik beroperasi pada pemilihan frekuensi yang akan difilter. Sedangkan di domain spasial, teknik beroperasi secara langsung pada piksel citra. Histogram Equalization (HE) adalah teknik yang telah terbukti mampu digunakan untuk meningkatkan kualitas pada citra terutama kontras karena kesederhanaan dan kemudahan implementasi. Histogram Equalization berfungsi meratakan distribusi kepadatan piksel dan secara dinamis membentangkan jangkauan dari tingkat keabuansehingga mampu untuk meningkatkan kontras keseluruhan citra. Histogram Equalization memanfaatkan Cumulative Density Function (CDF) dari citra untuk transformasi tingkat keabuancitra asli, sehingga dihasilkan citra hasil peningkatan. Kelemahan utama dari Histogram Equalization adalah bahwa metode ini cenderung untuk mengubah kecerahan rata-rata citra ke tingkat tengah rentang dinamis dan menghasilkan artifak dan efekintensitas saturasi. Kelemahan ini membuat teknik Histogram Equalization tidak cocok untuk sebagian besar aplikasi elektronik konsumen seperti TV dan Kamera. [1]

Teknik-teknik yang dibahas di atas tidak memberikan mekanisme untuk menyesuaikan tingkat peningkatan. Teknik baru berdasarkan perpotongan dari histogram diusulkan sebagai solusi untuk mengontrol laju peningkatan 
serta mempertahankan kecerahan aslinya. Dengan mengimplementasikan teknik perpotongan pada histogram mampu mengontrol nilai maksimum dari histogram dengan memotong nilai histogram lebih tinggi yang ditentukan oleh nilai ambang batas. Metode ini memberikan pendekatan yang berbeda dalam penentuan perpotongan nilai ambang.Makalah ini menyajikan Exposure based Sub-Image Histogram Equalization (ESIHE) sebagai metode baru untuk meningkatkan kontras pada citra dengan tingkatan skala keabuan.Nilai ambang dihitung untuk membagi citra asli ke sub-citra dari tingkat intensitas yang berbeda. Histogram juga dipotong menggunakan nilai ambang sebagai rata-rata jumlah kejadian tingkat keabuan untuk mengendalikan nilai piksel yang terlalu optimal. Histogram dari sub citra disamakan secara independen dan akhirnya semua sub citra diintegrasikan ke dalam satu citra yang lengkap agar selanjutnya dapat dianalisa. untuk analisis.

Pada Makalah ini akan diulas lebih detail di dalam bab-bab berikutnya. Pada bagian Metodologi Penelitian akan dijelaskan metode Exposure based Sub-Image Histogram Equalization (ESIHE) yang diusulkan. Kemudian pada Hasil dan Pembahasan menjelaskan hasil eksperimen perbaikan kualitas kontras citra menggunakan ESIHE yang akan dibandigkan dengan $\mathrm{HE}$.

\section{METODOLOGI PENELITIAN}

Data untuk penelitian ini menggunakan 10 data citra $X$-rayberupa otak, tulang, dan organ lainnya dari pasien. Data set dikumpulkan dari beberapa sumber media, yang berupa data public. Data citra $X$-ray yang digunakan diambil dari beberapa sumber data diantaranya adalah http://radiopaedia.org/.

Pada bagian ini akan dijelaskan bagaimana langkah-langkah yang harus diikuti untuk melakukan perbaikan kualitas kontras citra menggunakan metode ESIHE. Terdapat tiga langkah yaitu perhitungan ambang batas pencahayaan, perpotongan histogram, dan pemerataan histogram sub citra.

\subsection{Perhitungan Ambang Batas Pencahayaan}

Parameter ambang batas pencahayaan (exposure) didefinisikan sebagai yang menunjukkan alat ukur intensitas citra. Parameter ini digunakan untuk membagi citra yang tingkat pencahayaannya tinggi atau berlebih dan pencahayaan yang rendah atau kurang. Kemudian dinormalisasi dari nilai exposure 0-1. Jika nilai exposure untuk citra tertentu lebih dari 0,5 dan cenderung ke arah 1 , berarti bahwa citra memiliki tingkat pencahayaannya tinggi (over exposed) dan jika nilai ini kurang dari 0,5 dan cenderung ke arah 0 maka citra memiliki tingkat pencahayaan yang rendah atau kurang (under exposed). Dalam kedua kasus citra yang memiliki kontras yang rendah membutuhkan peningkatan kontras yang nilai pencahayaannya dapat dihitung menggunakan formula (1) pada sebagai berikut:

exposure $=\frac{1}{L} \frac{\sum_{k=1}^{L}{ }^{h}(k) k}{\sum_{k=1}^{L} \mathfrak{h}(k)}$

Dimana $h(k)$ adalah histogram dari citra dan L adalah jumlah total tingkat keabuan. Parameter lain $X a$ (yang dihitung dalam formula (2)) yang berhubungan dengan pencahayaan didefinisikan sebagai yang menyediakan nilai keabuan dan membagi citra yang pencahayaan rendah dan pencahayaan tinggi dari sub citra.

$X_{a}=L(1-$ exposure $)$

Parameter ini berisi nilai lebih besar atau lebih kecil dari L/2 (level keabuan) untuk nilai exposure yang lebih rendah atau lebih besar dari 0,5 masing-masing untuk citra yang memiliki nilai 0 sampai $\mathrm{L}$

\subsection{Perpotongan Histogram}

Ide di balik perpotongan histogram adalah untuk mencegah peningkatan berlebih yang mengarah ke penampilan alami citra. Untuk membatasi tingkat tambahan, kita perlu membatasi turunan pertama dari histogram atau histogram itu sendiri [3]. Nilai histogram memiliki nilai lebih besar dari perpotongan nilai ambang terbatas dari nilai ambang. Perpotongan nilai ambang dihitung sebagai rata-rata jumlah kejadian tingkat keabuan.

Formula untuk perpotongan batas ambang $T c$ disajikan dalam formula(3) dan formula(4) untuk menghitung perpotongan histogram. 
$T_{c}=\frac{1}{L} \sum_{k=1}^{L} h(k)$

$h_{e}(k)=T_{e}$ for $h(k) \geq T_{c}$

Dimana $h(k)$ dan $h c(k)$ adalah histogram yang asli dan histogram yang dipotong. Metode perpotongan histogram membuat proses komputasi menjadi efisien dan memakan waktu yang lebih rendah.

\subsection{Pemerataan Histogram Sub Citra}

Histogram asli pertama membelah berdasarkan nilai ambang batas pencahayaan $X a$ yang dihitung dalam formula (2). Histogram hasil proses dalam dua sub citra mulai dari abu-abu tingkat 0 untuk $X a$ dan $X a+1$ untuk L 1 dan dapat disebut sebagai pencahayaan rendah dan pencahayaan tinggi, seperti pada Gambar 1. $P L(k)$ pada formula (5) dan $P U(k)$ yang sesuai CDF dari sub citra sebagaimana didefinisikan dalam formula (6) dibawah ini.

$P_{L}(k)=\frac{\mathbb{N}_{L}[\mathbb{k} k)}{N_{L}}$ for $0 \leq k \leq x_{\sigma}$

$P_{U}(k)=h_{c} \frac{(k)}{N_{U}}$ for $X_{\square}+1 \leq k \leq L-1$

Dimana $N L$ dan $N U$ adalah jumlah piksel dalam masing-masing sub citra. $C L(k)$ dan $C U(k)$ yang sesuai CDF dari sub gambar dapat didefinisikan sebagai berikut.

$C_{L}(k)=\sum_{k=0}^{X_{M}} P_{L}(k)$

$C_{U}(k)=\sum_{k=X_{\text {a }}+1}^{L-1} P_{U}(k)$

Langkah berikutnya jika ESIHE adalah untuk menyamakan semua empat sub histogram secara individual. Fungsi transfer untukpemerataan histogram berdasarkan formula (7) dan Formula (8) dapat didefinisikan sebagai berikut.

$F_{L}=X_{a} x C_{L}$

$F_{U}=\left(X_{a}+1\right)+\left(L-X_{a}+1\right) C_{U}$

$F L$ dapat dihitung dengan menggunakan formula (9) dan $F U$ pada formula (10) adalah fungsi pengalihan yang digunakan untuk menyamakan sub histogram secara individual. Langkah terakhir melibatkan integrasi dari kedua sub citra menjadi satu citra yang lengkap. Perhitungan perpotongan histogram sub citra ditunjukkan pada gambar 1 .

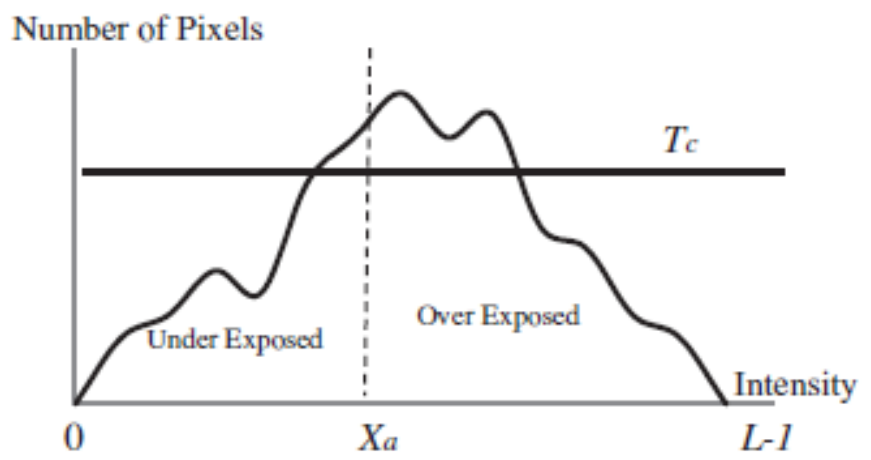

Gambar 1. Proses Perpotongan Histogram Sub Citra [2] 


\subsection{Algoritma ESIHE}

Berikut ini adalah pseucodetahapan metode Exposure based Sub-Image Histogram Equalization (ESIHE) menggunakan MATLAB.

Menghitung Histogram

$$
\mathrm{L}=256 \text {; }
$$

$\mathrm{x}=[0: 1: \mathrm{L}-1]$;

[w,l]=size(img);

len $=\mathrm{w} * 1$;

$\mathrm{y}=$ reshape(img,len,1);

$\operatorname{xpdf}=\operatorname{hist}(y,[0: L-1])$;

Proses Perpotongan Histogram

$\mathrm{Tc}=$ mean $(\mathrm{xpdf})$;

$\mathrm{Tc}=\operatorname{round}(\mathrm{Tc})$;

Ihist=zeros $(1,256)$;

for $\mathrm{i}=1: 256$

if $\operatorname{xpdf}(\mathrm{i})>\mathrm{Tc}$

Ihist $(\mathrm{i})=\mathrm{Tc}$;

elseif $\operatorname{xpdf}(i)==0$

Ihist $(i)=\operatorname{xpdf}(i)$;

else

$\operatorname{Ihist}(i)=\operatorname{xpdf}(i)$;

end

end

Pencahayaan Batas Ambang

exposure $=\operatorname{sum}(\mathrm{xpdf} . * \mathrm{x}) / \mathrm{sum}(\mathrm{xpdf}) /(\mathrm{L})$;

aNorm=(1-exposure);

$\mathrm{Xm}=$ round(L*aNorm);

METODE ESIHE

ESIHEoutput=zeros(size (img));

C_L $=$ zeros $(1, \mathrm{Xm}+1)$;

C_U $=$ zeros $(1,(256-(\mathrm{Xm}+1)))$;

n_L=sum(Ihist $(1: X m+1))$;

n_U $=\operatorname{sum}(\operatorname{Ihist}(\mathrm{Xm}+2: 256))$;

P_L=Ihist $(1: X m+1) / n \_L$;

P_U =Ihist $(X m+2: 256) / n \_U$;

C_L(1)=P_L(1);

for $\mathrm{r}=2$ :length $\left(\mathrm{P} \_\mathrm{L}\right)$

C_L $(r)=P \_L(r)+C \_L(r-1)$;

end

C_U(1)=P_U(1);

for $\mathrm{r}=2$ :(length $\left(\mathrm{P}_{-} \mathrm{U}\right)$ )

$C_{-} U(r)=P_{-} U(r)+C_{-} U(r-1)$;

end

for $\mathrm{r}=1$ : $\mathrm{w}$

for $\mathrm{s}=1: 1$

if $\operatorname{img}(\mathrm{r}, \mathrm{s})<(\mathrm{Xm}+1)$

$\mathrm{f}=\mathrm{Xm} * \mathrm{C} \_\mathrm{L}(\mathrm{img}(\mathrm{r}, \mathrm{s})+1)$;

$\operatorname{ESIHEoutput}(\mathrm{r}, \mathrm{s})=\operatorname{round}(\mathrm{f})$;

else

$\mathrm{f}=(\mathrm{Xm}+1)+(255-\mathrm{Xm}) * \mathrm{C}_{-} \mathrm{U}((\mathrm{img}(\mathrm{r}, \mathrm{s})-(\mathrm{Xm}+1))+1)$;

$\operatorname{ESIHEoutput}(\mathrm{r}, \mathrm{s})=\operatorname{round}(\mathrm{f})$;

end

end

end 


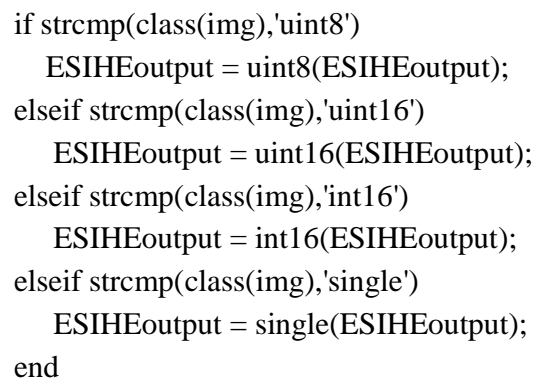

\section{HASIL DAN PEMBAHASAN}

Pada bagian ini, hasil simulasi dari metode yang diusulkan ESIHE dibandingkan dengan metode berbasis Histogram Equalization. Untuk menganalisis dan membandingkan metode yang ada kita gunakan sepuluh gambar $x$-ray yang perbandingan visual dapat ditunjukkan pada gambar 2 yaitu pada data 1 sampai dengan data 5 .

Penilaian kualitatif dari peningkatan kontras diperlukan bersama dengan penilaian kuantitatif. Hasil perbaikan kualitas gambar hanya dapat dihargai jika gambar yang dihasilkan memberikan efek yang bagus dari tingkat pencahayaan yang cukup dalam penampilan gambar asli. Dengan penilaian kualitas visual yang dimiliki pencahayaan yang kurang, harus lebih ditingkatkan atau dilakukan dengan peningkatan tidak wajar. Hasil penilaian visual ukuran kualitas yang efektif untuk menilai kinerja algoritma peningkatan kontras.

\begin{tabular}{|c|c|c|c|}
\hline Nama Citra & Citra Asli & HE & ESIHE \\
\hline Data1.jpg & & & \\
\hline Data2.jpg & & & \\
\hline Data5.jpg & & & \\
\hline & & & \\
\hline & & & \\
\hline
\end{tabular}

Gambar 2. Hasil Perbandingan Perbaikan Kualitas Citra antara HE dan ESIHE 


\subsection{Pengukuran Rata-rata Kandungan Informasi (Entropy)}

Untuk mengevaluasi kinerja ESIHE, rata-rata kandungan informasi yang digunakan sebagai kualitas gambar ukuran rata-rata kandungan informasi (entropy) adalah ukuran rincian gambar dan biasanya diukur dalam satuan sebagai bit. Entropy sini disebut adalah Shannon Entropy dan mengukur ketidakpastian terkait dengan tingkat abuabu dalam gambar. Nilai yang lebih besar dari entropy menunjukkan bahwa informasi lebih banyak konten tersedia dalam gambar [4]. Formula (11) digunakan untuk yang menjelaskan perhitungan entropy.

$E N T(p)=\sum_{l=0}^{L-1} P(l) \log P(l)$

Dimana $P(l)$ adalah Cumulative Density Function (CDF) dari citra yang diberikan pada tingkat intensitas $l$ dan $L$ adalah jumlah total tingkat abu-abu dalam gambar. Sebuah gambar dengan nilai entropy yang lebih tinggi memiliki informasi yang detail dan dianggap memiliki kualitas yang lebih baik. Seperti yang ditunjukkan pada Tabel 1.

Tabel 1. Hasil Komparasi Pengukuran Entropy dengan Metode HE dan ESIHE

\begin{tabular}{|c|c|c|c|}
\hline Nama Gambar & Citra Asli & $H E$ & ESIHE \\
\hline Data1.jpg & 6.6686 & 5.4388 & 6.5750 \\
\hline Data2.jpg & 6.5392 & 5.1658 & 6.4242 \\
\hline Data3.jpg & 4.3105 & 3.2942 & 4.2121 \\
\hline Data4.png & 5.4824 & 4.2156 & 5.3845 \\
\hline Data5.jpg & 6.6719 & 5.4099 & 6.5806 \\
\hline Data6.jpeg & 6.3011 & 4.9587 & 6.1885 \\
\hline Data7.jpg & 4.2544 & 3.1867 & 4.2100 \\
\hline Data8.jpg & 6.9204 & 5.5947 & 6.8352 \\
\hline Data9.jpg & 6.8929 & 5.4592 & 6.7955 \\
\hline Data10.jpg & 7.3586 & 5.9207 & 7.2895 \\
\hline Rata-Rata & 6.1400 & 4.8644 & 6.0495 \\
\hline
\end{tabular}

\section{KESIMPULAN}

Dalam penelitian kali ini menyajikan sebuah metode baru menggunakan teknik histogram untuk peningkatan gambar warna terang (exposure). Pencahayaan berdasarkan gambar asli dan pemerataan histogram sub gambar terbukti merupakan teknik yang sangat efektif untuk meningkatkan pencahayaan yang kurang. Teknik perpotongan histogram juga dikombinasikan dengan pemerataan histogram (Histogram Equalization). Teknik ini dapat memberikan kontrol lebih dari peningkatan yang mengarah ke peningkatan alami. Berdasarkan langkah-langkah entropy yang telah dilakukan menggunakan metode ESIHE terbukti menunjukkan perolehan nilai rata-rata lebih dibandingkan dengan menggunakan metode HE. Sedangkan untuk hasil kualitas visual gambar ESIHE menunjukkan hasil yang lebih handal dari pada metode HE untuk berbagai macam gambar $x$-ray.

\section{DAFTAR PUSTAKA}

[1] Gonzalez, R.C., and Woods, R.E., (2002). Digital Image Processing, third edision. Prentice Hall, chapter 3:122-125

[2] Hanmandlu, M., Verma, O.P., Kumar, N.K., Kulkarni, M., 2009. “A Novel Optimal FuzzySystem for Color Image Enhancement using Bacterial Foraging”. IEEE Trans. Inst.Meas. 58 (8), 2867-2879.

[3] Ooi, C.H., Kong, N.S.P., Ibrahim, H., 2009. "Bi-Histogram Equalization with APlateauLimit for Digital Image Enhancement”. IEEE Trans. Consumer Electron. 55 (4),2072-2080.

[4] Chen, S.D., 2012. “A New Image Quality Measure for Assessment of Histogram Equalization-Based Contrast Enhancement". Digital Signal Process. 22 (April),640-647.

[5] Sim, K.S., Tso, C.P., Tan, Y.Y., 2007. “Recursive Sub-Image Histogram Equalization Applied to Gray Scale Images". Pattern Recogn. Lett. 28 (10), 1209-1221. 